\title{
Analysing the perception and usage of local textile prints a study of koforidua technical university
}

\author{
Richard Amoasi, Seth Osei-Tutu Tuffour, Samuel Owusu Ansah
}

\author{
Faculty of Business and Management Studies Koforidua Technical University \\ Faculty of Business and Management Studies Koforidua Technical University \\ Koforidua Technical University Marketing Department
}

\begin{abstract}
People all over the world portray different attitudes towards the same stimuli. This is because individuals have different perceptions about a particular stimulus. Obviously, consumer perception and attitudes towards their own country's products keeps on changing. Personal observations and empirical evidence shows that Ghanaian textile industry have not been able to achieve its set objectives due to inappropriate product marketing and this has influenced the perceptions people greatly towards the Ghanaian prints. The aim of the study is to determine what is responsible for the perceptions towards made-in-Ghana textiles and to ascertain what can be done to influence the perception towards the Ghanaian textiles. The sample size consisted of two hundred [200] respondents mainly from selected staff and students of Koforidua Technical University. Both primary data and secondary data and interviews and questionnaires to gather the relevant data needed for the research were used. Statistical tools such as tables and bar graphs were used for the analysis. The study revealed that students of Koforidua Technical University are generally satisfied with made-in-Ghana textiles but had some dissatisfaction with the prices of these textiles. The study suggested that the Ghana textile industry should make their products more price competitive to encourage sales increase and to discourage the influx of the local designs from foreign markets into the country.
\end{abstract}

\section{Introduction}

People all over the world portray different attitudes towards the same stimuli. This is because individuals have different perceptions about particular stimulus. Mostly people perceive things based on information, and experience they have acquired about stimulus and this can be seen in the textiles industries. Increased travel, education, as well as improved communication such as the global spanning television networks, internets and culture have contributed to a convergence of taste, preferences, attitudes and perceptions in a number of textiles and garment products of different origin.

Obviously, consumer perception towards their own country's products keeps on changing positively unlike the previous times. The history overview of the Ghana textiles printing industry over the period of their establishment shows that factories have never enjoyed full patronage of their products. The products from Takoradi Textiles Limited (TTL) and Ghana Textiles Manufacturing Company (GTMC) for example were selling at one cedi per yard, the cloth came to be called 'cedi tam' a slogan which signifies inferior product quality. Since then Ghanaian consumers have generally expressed negative perceptions towards the locally produced prints in favour of Western imported textile products.

Fortunately in the year 2000, the USA government enacted and passed a law; an initiative that helped revive the ailing industries in the sub- Saharan African continent. This is what is referred to as the African Growth and Opportunity Act (AGOA) under the Bill Clinton administration with special emphasis on textiles and apparels. Due to this, a critical attention was given to Ghanaians textiles industries under the2001 Presidents Special Initiative (PSI) Here in referred to as President's Special Initiative on Textiles and Garment(PSIOTG) Consequently, the Nation Friday Wear (NFW) programme was also implemented to 
facilitate the patronage of locally produced textiles. According to 2005 September press briefing, the then Minister for Private Sector Development and PSI; Hon:Kwamena Bartels stated that government through intervention of the PSI which is one of the three- pronged approaches among stated plans is to accelerate the economic growth of the country and help reduced poverty among Ghanaians especially the youth. Ghanaians are supposed to appreciate their own made print and patronized it but unfortunately Ghanaians seems to prefer other print due to a negative stereo-type.

Personal observation and empirical evidence show that the Ghanaian textiles industry has not been able to achieve it set objectives due to inappropriate product marketing and this has influenced the perceptions towards the Ghanaian textile prints. Although a few people seem to wear made in Ghana textiles, preliminary investigations show that few studies have been carried out yet on people's perception towards made in Ghana textiles. The study therefore intends to investigate the general perceptions towards made in Ghana textiles. The emphasis of this work is on the perception towards made in Ghana textiles with the respect to the marketing mix.

\section{Literature Review \\ Perception and stimuli}

Perception form part of the psychological influences on the buying decision process of every individual. People all over the world have different perceptions towards products or services organizations offer. These different perceptions customers have make them behave differently towards a given stimuli. Boone and Kurtz (2000) define perception as a person's attribute to incoming stimuli gathering through the five (5) senses [that is sight, touch, hearing, smell and taste]. Mowen (2001) defines perception as the process through which individuals are exposed to information, attend to the information and comprehend the information. He also defines it as a way in which people organize information so that it has a meaning. Pride-Ferrell (2003) defines perception as the process of selecting, organizing and interpreting information input to produce meaning. The kind of stimuli received by the consumer influences perception. O1: in which way are consumers behaviour influenced towards made-in-Ghana textiles.

\section{Exposure and perception influence}

Before any type of marketing stimuli can affect consumers, they must first be exposed to it. Exposure simply reflects to process by which the consumer comes into physical contact with a stimuli. McLuhan (2000) "people wear their own set of idiosyncratic goggles" meaning every individual holds a unique view of what the world looks like and how it happens. This led to the second objective O2: how can the consumers' attitude be influenced towards the made-in-Ghana textile?

\section{Other factors that influences consumers' attitude towards the local textiles}

National and international market recognize that consumers have either positive or negative feelings towards products depending on how they perceive quality, accessibility, security, warranty, goodwill and some other factors(Watson and Wright 2000). There is also an issue of positive and negative bias. Negative bias appears in form of a dislike for foreign products (Shimp and Sharma 1987). Consumers may also have positive perception towards a product. This has to do more with products that are coming from countries that are culturally similar to the home country. (Heslop et at 1998, Lantz \& Loeb 1996). There is evidence to support the facts that products made from developed countries, particularly the Western world are of superior value to those produced in developing countries (Bilkey and Nes, 1982) Foreigners pick the Ghanaian designs to produce textile prints. Ghanaians prefer the Ghanaian design but foreign print than the same design printed locally. This led to the third objective O3: what factors do consumers consider in selecting the local textiles for use?

\section{Methods}

Qualitative and quantitative methods were used in the empirical segment of the study. (Terre Blanche, Durrheim \& Painter 2006) The study population is the aggregation of the element from which the sample is actually selected. The researcher used probability and non-probability sampling technique to increase the chances of each respondent been selected for the survey. The sampling size of two hundred [200] respondents were used for the study and the target population was local print users of between the ages of 18 
to 35 years. The size was chosen because of the limited scope for the study. Questionnaires were administered to the students and staff of the various faculties of Koforidua Technical University.

\section{Data collection}

Questionnaires were used to obtain information from the target population. This instrument was considered because its possibility of reaching respondents is much greater than with the other methods and also give respondents the opportunity to answer the questionnaire at their own convenience and to avoid any bias in the way questions asked. The questionnaire was divided into three sections. Section A elicited general and biographical information about respondents. Section B sought information of perception and Section C sought for information on other factors that influences consumers attitude towards a product ( local prints). Interviews were also used to retrieve detailed information from the right respondents who were capable of providing reliable and accurate information and also to express their views in connection to the topic under study.

\section{Data analysis}

After collecting the data, standard editing and coding procedures were used to clean and prepare data for analysis. The data gathered was entered into a computer using the SPSS. Statistical tools like tables, bar charts were used. These statistical tools were used for easy interpretation and understanding of the research work.

\section{Result and Discussion}

Following the guidelines indicated in the research methodology section, the researcher collected data in July, 2018.

The Use Of Made-In-Ghana Textiles Among People Table 1: A table showing the results of the use of made-in-Ghana textiles among people

\begin{tabular}{|c|c|c|}
\hline Response & Frequency & Percentage [\%] \\
\hline Yes & 175 & 97.2 \\
\hline No & 5 & 2.8 \\
\hline Total & $\mathbf{1 8 0}$ & $\mathbf{1 0 0}$ \\
\hline
\end{tabular}

\section{Source: field survey, JULY 2018}

Table1 illustrates that out of the one hundred and eighty [180] respondents; one hundred and seventy-five [175] use made-in-Ghana textiles/prints which represent ninety-seven point two percent [97.2\%] of the total respondents and five [5] do not use made-in-Ghana textiles representing two point eight percent [2.8\%] of the total respondents. This indicates that most of the people in Koforidua Municipality use made-in-Ghana textiles. Perhaps, because of the positive perception they hold about made-in-Ghana textiles. Such as Woodin, ATL, GTP, polished cotton etc. Most of them said they are now used to the wearing of the local textiles due to the material Friday Wear and more importantly motivated by the fact that the President of the country is seen wearing it every day. 
Textiles/Prints Used By Respondents

Table 2 : A table showing the textiles/prints used by the respondents.

\begin{tabular}{|c|c|c|}
\hline Textiles & Frequency & Perception [\%] \\
\hline Atl & 10 & 5.7 \\
\hline Atl, Batik & 8 & 4.6 \\
\hline Batik & 10 & 5.7 \\
\hline Batik, GTP & 6 & 3.4 \\
\hline Batik, GTP, ATL & 6 & 3.4 \\
\hline $\begin{array}{c}\text { Batik, GTP, ATL, Tie } \\
\text { And Dye }\end{array}$ & 9 & 5.1 \\
\hline Batik, Gtp, Printex & 8 & 4.6 \\
\hline Batik, Printex & 11 & 6.3 \\
\hline Gtp & 5 & 2.9 \\
\hline Gtp, Atl & 7 & 4 \\
\hline Gtp, Printex, Atl & 10 & 5.7 \\
\hline Gtp, Printex & 10 & 5.7 \\
\hline GTP, Tie And Dye & 11 & 6.3 \\
\hline Printex & 14 & 8 \\
\hline Tie And Dye & 13 & 7.4 \\
\hline Tie And Dye, Batik & 12 & 6.9 \\
\hline Others & 25 & 14.3 \\
\hline Total & 175 & 100 \\
\hline
\end{tabular}

\section{Source: Field survey, JULY 2018}

From the table above, out of 175 respondents who use Made-in-Ghana textiles, ten [10] of the respondents which represents five point seven percent [5.7\%] of the total respondents prefer ATL, eight [8] which represents four point six percent [4.6] prefer ATL, and Batik, ten [10] which represents five point seven percent [5.7\%] prefer only Batik, six [6] which represents three point four percent [3.4\%] prefer Batik, and GTP, six [6] of the respondents which represents three point four percent[3.4\%] prefer Batik, GTP, and ATL, nine [9] which represents five point one percent [5.1] prefer Batik, GTP,ATL and Tie and Dye, eight [8] which represents four point six percent [4.6\%] use Batik, GTP and Printex, eleven [11] which represents six point three percent [6.3] use Batik and Printex, five [5] which represents two point nine percent [2.9\%] prefer the use of GTP only, seven [7] which represents four percent [4\%] prefer GTP and ATL, ten [10] which represents five point seven percent [5.7\%] prefer the use of GTP, Printex and ATL, ten [10] which represents five point percent [5.7\%] of the total respondents prefer GTP, and Printex, eleven [11] which represents six point three percent [6.3\%] prefer GTP, and Tie and Dye, fourteen [14] which represents eight percent [8\%] use only Printex, thirteen [13] which represents seventy point four percent [7.4\%] prefer Tie and Dye, twelve [12] which represents six point nine percent [6.9\%] of the respondents prefer Tie and Dye, and Batik and twenty-five [25] which represents fourteen point three percent [14.3\%] of the total 
respondents of the study prefer the use of the Made-in-Ghana textiles. The analysis shows that the respondents have the taste for varied Made-in-Ghana textiles. The wide distribution of the net of the local textiles shows the perception of the people towards the locally produced textiles is increasingly positive.

\section{Perception Of Quality Of Textiles /Local Prints Compared To Foreign Textiles}

Fig 1: A bar chart showing the distribution response towards the perception of quality of local prints/textiles.

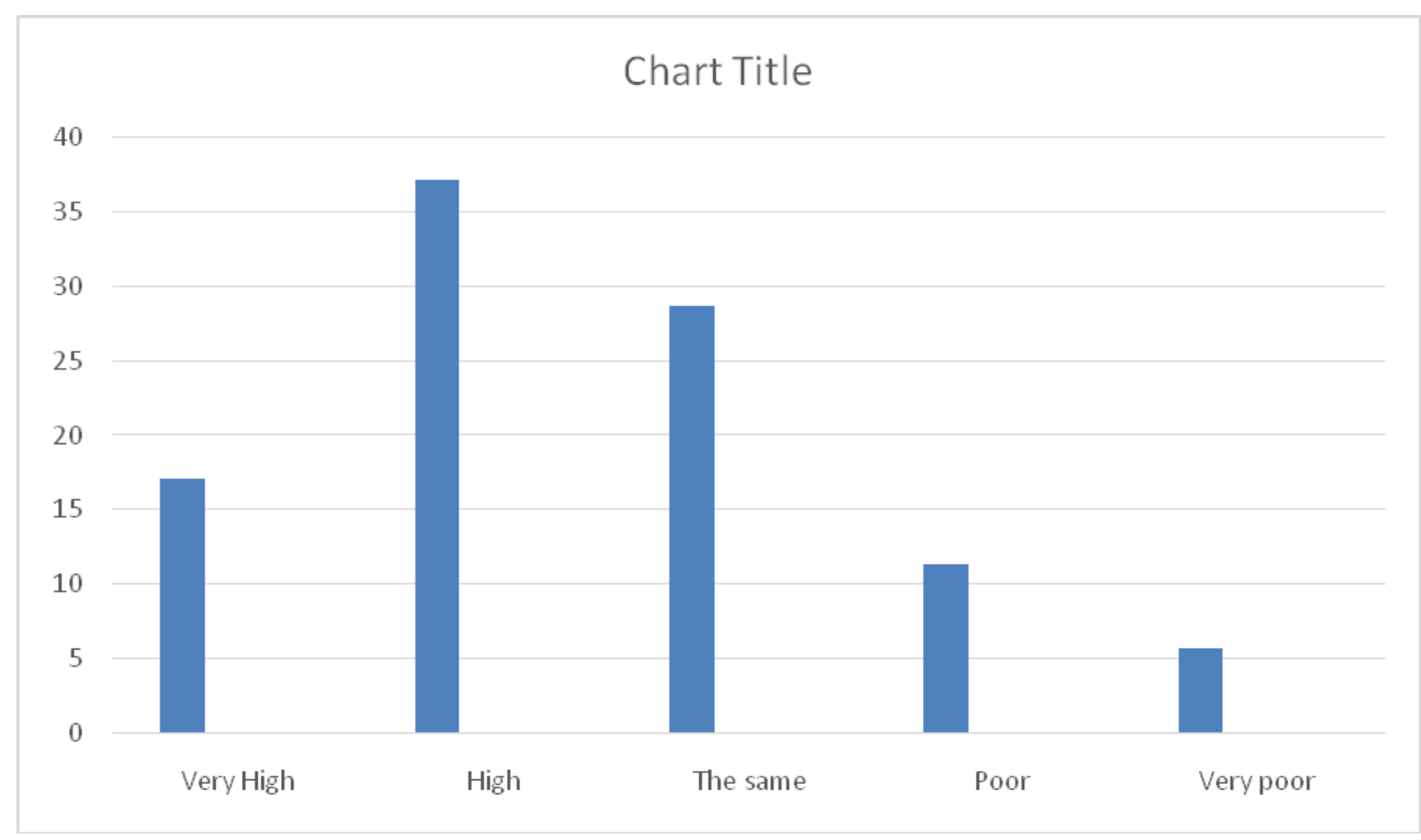

Source: Field Survey, JULY 2018

From the graph above, the respondents rated the locally made-in-Ghana textiles to be of high quality as compared to that of the foreign textiles. This is because out of the total respondents, thirty [30] of them which represents seventeen point one percent [17.1\%] said the made-in-Ghana textiles is of very high quality as compared to the foreign textiles. Sixty-five [65] of the respondents which represents thirty-seven point one percent [37.1\%] said it is of high quality, fifty [50] respondents which represents twenty-eight point six percent [28.6\%] of the total respondents said both made-in-Ghana textiles and the foreign one are of the same quality, twenty [20] of the respondents which represents eleven point four percent [11.4\%] of the respondents said locally made textiles is of poor quality, and ten (10) respondents which represents five point seven percent $(5.7 \%)$ of the total respondents of the study said the quality of locally made textiles are very poor. This indicates that, some of the respondents hold the view that the locally manufactured textiles are inferior to the foreign textiles. The local manufacturing companies must endeavor through the marketing communication efforts to change the negative perception and poor attitudes of some of the respondents towards the local textiles. 


\section{Level of statisfaction derived from sewing local prints}

Fig 2: A bar chat [showing percentage response level of satisfaction derived from sewing the local fabric/textile.

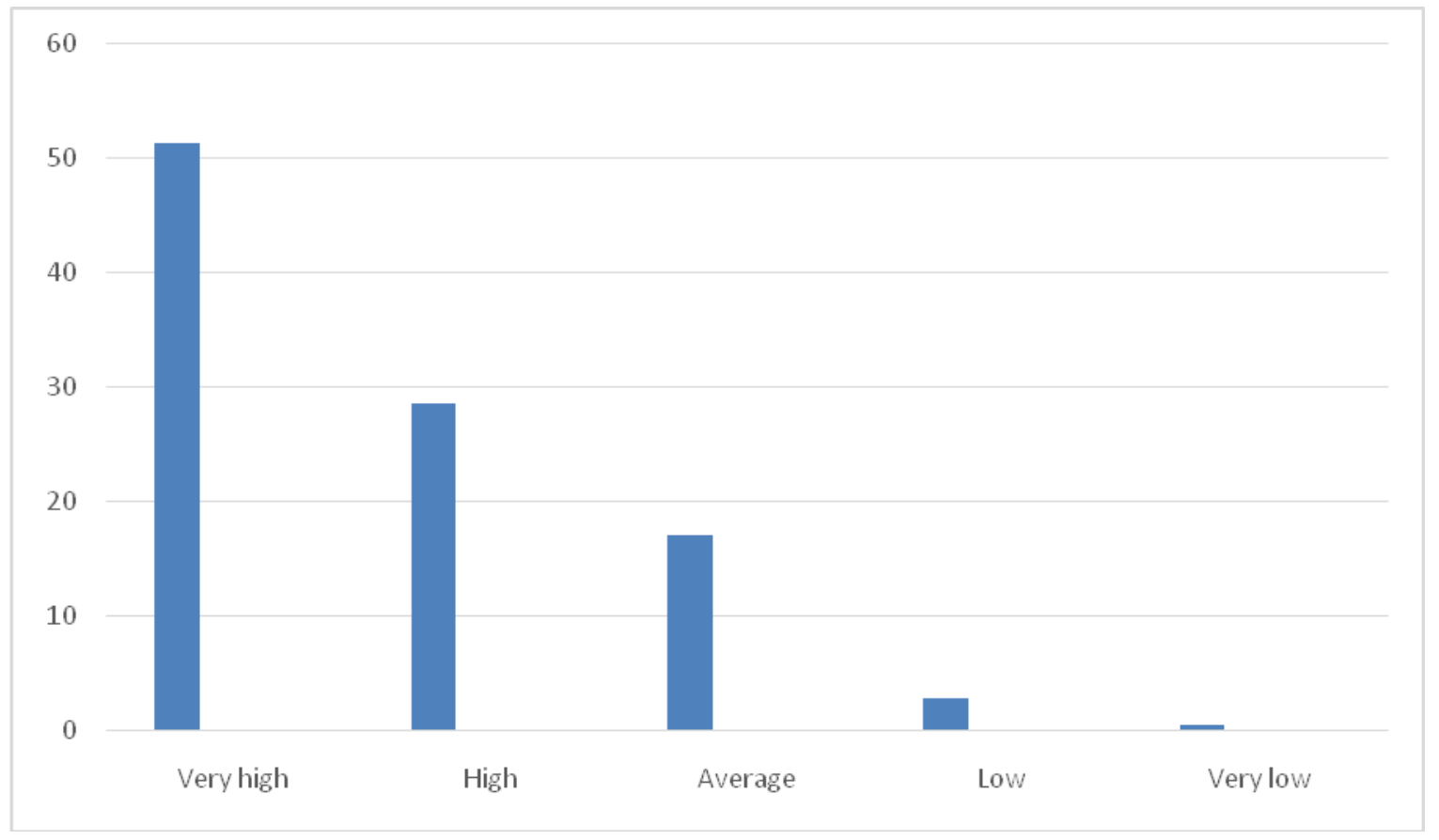

\section{Source: Field survey, JULY 2018}

From the chart above, ninety (90) respondents representing fifty-one point four percent $(51.4 \%)$ were very satisfied for using Made-in-Ghana textiles to sew their own dresses. Fifty (50) of the respondents representing twenty-eight point six percent $(28.6 \%)$ were satisfied for using or wearing dresses derived from sewing Made-in-Ghana textiles. Thirty (30) respondents representing seventeen point one percent (17.1\%) were averagely satisfied and a total of five (5) respondents representing two point nine percent (2.9\%) had low and very low satisfaction derived from the use of sewing dresses from the local fabrics. Though a very high response indicates respondents are satisfied with the use of local fabrics, the firm producing them must do all in their means to retain the customers and to win the other respondents that seem not satisfied for them to generate interest and or build positive perception towards the use of the local textiles.

Perception towards branding of finished local prints clothes/fabrics. Table 3: A table illustrating perception towards Branding Of Finished Local Prints Clothes/Fabrics.

\begin{tabular}{|c|c|c|}
\hline Rating & Frequency & Percentage\% \\
\hline Yes & 100 & 57.1 \\
\hline No & 75 & 42.9 \\
\hline Total & $\mathbf{1 7 5}$ & $\mathbf{1 0 0}$ \\
\hline
\end{tabular}

Source: Field Survey, JULY 2018

From table 3 above, out of the 175 respondents, hundred (100) respondents representing fifty-seven point one percent $(57.1 \%)$ said Made-in-Ghana clothes are branded and seventy-five percent (75) of the total respondents representing forty-two point nine percent (42.9\%) said they are not branded. This indicates that most Ghana made fabrics or clothes are perceived to be branded. Marketing communications efforts towards enhancing the branding and names of the Made-in-Ghana clothes should be made and communicated to the respondents more frequently considering the time and medium to be based for effective change of perception towards the branding of the Made-in-Ghana clothes. 
Level of Attractiveness Of The Local Brand Names

Table 4: A table illustrating the perception level of attractiveness of the local brands names.

\begin{tabular}{|c|c|c|}
\hline RATING & FREQUENCY & PERCENTAGE \% \\
\hline VERY & 50 & 28.6 \\
\hline ATTRACTIVE & 100 & 57.1 \\
\hline NOT SURE & 20 & 11.4 \\
\hline UNATTRACTIVE & 5 & 2.9 \\
\hline VNERY & 0 & 0 \\
\hline TOATRACTIVE & $\mathbf{1 7 5}$ & $\mathbf{1 0 0}$ \\
\hline
\end{tabular}

Source: Field Survey, JULY 2018

Out of the one hundred and seventy-five [175] respondents, fifty (50) respondents representing twenty-eight point six percent (28.6\%) perceive brand names of Made-in-Ghana clothes as very attractive, hundred (100) respondents representing fifty-seven point one percent $(57.1 \%)$ perceive brand names of Made-in-Ghana clothes as attractive. The remaining twenty-five (25) of the total respondents representing fourteen point three percent (14.3\%) are not sure whether it is attractive and see it as not attractive. The designers must ensure that they use names, signs, symbols, etc. that are easily memorable, recognized, pronounce and spelt. They must enhance their brand equity efforts by making sure they achieve brand recall for their brands.

Package of made-in-ghana clothes.

Table 5: A table illustrating the response on whether made-in-Ghana clothes are packaged.

\begin{tabular}{|c|c|c|}
\hline RATING & FREQUENCY & $\begin{array}{c}\text { PERCENTAGE } \\
\%\end{array}$ \\
\hline Yes & 160 & 91.4 \\
\hline No & 15 & 8.6 \\
\hline Total & $\mathbf{1 7 5}$ & $\mathbf{1 0 0}$ \\
\hline
\end{tabular}

Source: Field Survey, JULY 2018

From the above table, it can be seen that out of the total respondents, one hundred and sixty (160) representing ninety-one point four percent $(91.4 \%)$ of the respondents see that Made-in-Ghana clothes are packaged while the remaining fifteen (15) respondents representing eight point six percent $(8.6 \%)$ perceive it to be not packaged. This indicates that most made-in-Ghana clothes are packaged. Seamstress and other fashion designers who hang their products by the street sides must desist from that act but emulate the footsteps of other known designers who package their products in other to change their negative attitude perception of respondents towards Made-in-Ghana clothes. 
Rating of prices of made-in-ghana textiles.

Table 6: A table showing the Rating of Prices of the Local Prints/ Textile Clothes

\begin{tabular}{|l|l|l|}
\hline PRICE & FREQUENCY & PERCENTAGE \% \\
\hline Very high & 40 & 22.9 \\
\hline High & 100 & 57.1 \\
\hline Moderate & 20 & 11.4 \\
\hline Low & 10 & 5.7 \\
\hline Very low & 5 & 2.9 \\
\hline Total & $\mathbf{1 7 5}$ & $\mathbf{1 0 0}$ \\
\hline
\end{tabular}

Source: field survey, JULY 2018

The information above shows that forty (40) respondents representing twenty-two point nine percent $(22.9 \%)$ of the total respondents were of the view that the prices of made-in-Ghana clothes are very high, one hundred (100) respondents which represents fifty-seven point one percent $(57.1 \%)$ were of the view that prices are high, twenty (20) of the respondents representing eleven point four percent (11.4\%) view prices as moderate, and the remaining fifteen (15) of the respondents representing eight point six percent $(8.6 \%)$ view prices to be low. This indicates that made-in-Ghana clothes /textiles are quite expensive on the market. Designers and manufacturing companies therefore must consider the various economic classification or levels in the market and then manufacture and design clothes to suit them. This may reduce the perception of some respondents that the product's prices are high. The researcher suggests that since Ghanaians have taste for foreign clothes/dresses, the manufactures of these textiles must adopt price penetration strategy in order to increase sales, stimulate growth and increase market share [Kotler 2010]

Rating of available of local prints of textiles on the market.

Table 7: A table showing respondents' rating of level of availability of Local Prints/textile clothes on the markets.

\begin{tabular}{|c|c|c|}
\hline Levels of availability & Frequency & Percentage[\%] \\
\hline Very often available & 43 & 24.6 \\
\hline Often available & 100 & 57.1 \\
\hline Available & 20 & 11.4 \\
\hline Often not available & 10 & 5.7 \\
\hline Not available & 2 & 1.1 \\
\hline Total & $\mathbf{1 7 5}$ & $\mathbf{1 0 0}$ \\
\hline
\end{tabular}

Source: Field survey, JULY 2018

The above information shows that forty-three [43] respondents representing twenty-four point six percent [24.6\%] of the total respondents were of the view that Made-in-Ghana textiles are very often available in the market, one hundred [100] respondents with the percentage of fifty seven point one percent [57.1\%] represents the respondents who think that Made-in-Ghana textiles are often available in the market, twenty [20] of the respondents representing eleven point four percent [11.4\%] of the total respondents think they are available and the remaining twelve [12] representing six point eight percent [6.8\%] of the total respondents think that Made-in-Ghana textiles are not available on the market. This implies that, Made-in-Ghana textiles are accessible and available in the market place. Though the perception of availability of Made-in-Ghana textiles is high, the designers and manufacturing companies must ensure that the six point eight percent 
[6.8\%] respondents who have the negative perception on the product's availability change. In this light the researcher suggests that dealers and retailers must ensure that they have stocks for all the brands all the time.

Perceived Rate of Advertising Effectiveness

Table 8: A table showing rate of advertising effectiveness on Local Prints/ textiles

\begin{tabular}{|c|c|c|}
\hline $\begin{array}{c}\text { Advertising } \\
\text { Effectiveness }\end{array}$ & Frequency & Percentage[\%] \\
\hline Very effective & 10 & 5.7 \\
\hline Effective & 20 & 11.4 \\
\hline Available effective & 30 & 17.1 \\
\hline Ineffective & 76 & 43.2 \\
\hline Very ineffective & 39 & 22.3 \\
\hline Total & $\mathbf{1 7 5}$ & $\mathbf{1 0 0}$ \\
\hline
\end{tabular}

Source: Field survey, JULY 2018

The table above shows that, out of the total respondents, ten [10] of the respondents representing five point seven percent [5.7\%] perceive advertising of Made-in-Ghana textiles as very effective, twenty [20] of the respondents which represent eleven point four percent [11.4\%] perceive it as effective, thirty [30] of the respondents representing seventeen point one percent [17.1\%] perceive it as averagely effective and the remaining one hundred and fifteen [115] representing sixty-five point five percent [65.5] perceive it as ineffective. This implies that Ghanaian textiles companies do not advertise and that those who advertise, the advertisement is ineffective. Both the manufacturers of the textiles and the designers must be effective in their advertising campaign. Adverts should be targeted towards the entire market. Since it is almost becoming a norm that everyone within the work force wears a locally manufactured textile at least one day in a week. Even for Junior High School and Senior High School Students.

Rate of usage /wearing local prints of textiles

Table 9: A table illustrating the rate of usage/wearing local prints/textiles

\begin{tabular}{|c|c|c|}
\hline Rating & Frequency & Percentage[\%] \\
\hline Once & 40 & 22.9 \\
\hline Twice & 83 & 47.2 \\
\hline Thrice & 14 & 8 \\
\hline Four times & 13 & 7.4 \\
\hline Five times & 15 & 8.6 \\
\hline Six times & 6 & 3.4 \\
\hline Throughout the week & 4 & 2.3 \\
\hline Total & $\mathbf{1 7 5}$ & $\mathbf{1 0 0}$ \\
\hline
\end{tabular}

Source: Field survey, JULY 2018

From the table above it can be seen that out of the total respondents, forty [40] of the respondents representing twenty-two point nine percent [22.9\%] of the respondents wear Made-in-Ghana textiles only once a week, eighty-three [83] respondents which represent forty-seven point two percent [47.2\%] of the respondents wear Made-in-Ghana textiles only twice a week, fourteen [14] respondents representing eight percent [8\%] of the respondents wear Made-in-Ghana textiles thrice a week, thirteen [13] respondents 
representing seven point four percent [7.4\%] of the respondents wear Made-in-Ghana textiles four times a week, fifteen [15] respondents which represents eight point six percent [8.6] of the respondents wear madein-Ghana textiles five times a week, six [6] respondents representing three point four percent [3.4\%] of the respondents wear Made-in-Ghana textiles six times a week, and four [4] of the respondents representing two point three percent [2.3\%] of the respondents wear Made-in-Ghana textiles throughout the week. This depicts that, most of the respondents wear locally manufactured textiles at least twice a week. It was also discovered that majority of the respondents who wear the local textiles for more than four times in a week were adults and most of them too were dealers of the local textile prints. Companies and other institutions such as the tertiary institutions must ensure the frequent use of the locally manufactured textiles sewn into clothes. In as much as it will promote the use and increase perception towards Made-in-Ghana textiles, it will also lead to the sustainability of the manufacturing firms and creates more jobs.

Level of satisfaction derived from made-in-ghana textiles

Table 10: A table showing the level of satisfaction derived from Made-in-Ghana/Local textiles

\begin{tabular}{|l|l|c|}
\hline Level of satisfaction & Frequency & Percentage[\%] \\
\hline Very satisfied & 47 & 26.9 \\
\hline Satisfied & 79 & 45.1 \\
\hline Average satisfied & 38 & 21.7 \\
\hline Unsatisfied & 9 & 5.1 \\
\hline Very unsatisfied & 2 & 1.1 \\
\hline Total & $\mathbf{1 7 5}$ & $\mathbf{1 0 0}$ \\
\hline
\end{tabular}

Source: Field survey, JULY 2018

From the information above, forty seven [47] respondents representing twenty-six point nine percent [26.9\%] of the total respondents were very satisfied with Made-in-Ghana textiles, seventy-nine [79] of the respondents representing forty five point one percent [45.1\%] of the total respondents were satisfied with made-in-Ghana textiles, thirty-eight [38] of the respondents representing twenty point seven percent [21.7\%] of the total respondents were averagely satisfied with Made-in-Ghana textiles, the remaining eleven [11] of the respondents representing six point two percent [6.2\%] of the total respondents were not satisfied with Made-in-Ghana textiles. This indicates that most of the respondents are satisfied with Made-in-Ghana textiles. In as much as a higher percentage of the respondents were satisfied with Made-in-Ghana textiles, the designs and styles must suit and appeal to the target audience to enhance the continual usage or patronage of the Made-in-Ghana textiles. 
Perceived changes to be effected in local prints companies to influence perception and usage. Table 11 : A table showing what should be change in made-in-Ghana Prints companies to influence perception and usage.

\begin{tabular}{|l|c|c|}
\hline & Frequency & Percentages \% \\
\hline $\begin{array}{l}\text { Increase promotional activities about the } \\
\text { textiles }\end{array}$ & 38 & 21.7 \\
\hline $\begin{array}{l}\text { Reduce the price of textiles } \\
\begin{array}{l}\text { Government should provide policies to } \\
\text { enforce usage of the textiles }\end{array}\end{array}$ & 60 & 34.3 \\
\hline $\begin{array}{l}\text { High import duties on imported textiles } \\
\text { and the ban of China prints. }\end{array}$ & 25 & 9.7 \\
\hline $\begin{array}{l}\text { Improve on the designs of the clothes. } \\
\text { Total }\end{array}$ & 35 & 14.3 \\
\hline
\end{tabular}

Source: Field survey, JULY 2018

The information above shows that out of the total respondents, twenty-one point seven percent [21.7\%] would like Ghanaian textiles companies to intensify their promotional activities about their range of products, thirty-four point three percent [34.3\%] of the respondents would like the prices of the textiles to be reduced, nine point seven percent [9.7\%] suggested government should provide policies to enforce usage rate, fourteen point three percent[14.3\%] would like import duties to be increased on imported textiles so to make the prices of the foreign products higher in comparison to the local prints and twenty percent [20\%] of the respondents would like the designs of the textiles to improve.

\section{Percetion Of The Local Prints}

Table 12: A table illustrating what result in the respondents perception of local prints.

\section{DATA PRESENTATION AND ANALYSES}

\section{- 4.6 PERCETION OF THE LOCAL PRINTS}

- Table 7: A table illustrating what result in the respondents perception of local prints.

\begin{tabular}{|l|l|l|}
\hline Responses & frequency & Percentage(s) \\
\hline $\begin{array}{l}\text { Lack of } \\
\text { information } \\
\text { e\} }\end{array}$ & 66 & 38 \\
\hline $\begin{array}{l}\text { Preference and Usage } \\
\text { Experimental factors }\end{array}$ & 45 & 25 \\
\hline Totals & 64 & 37 \\
\hline
\end{tabular}

Source: Field survey JULY, 2018 
From the data that was gathered and analysed, sixty-three (63\%) percent of the respondents stated that they do not know much about the local prints because they grew up to meet foreign prints and that they don't have much information on the local prints and that has resulted in their use and preference for second hand clothes (ofos) as commonly use in our local palance. Thirty-seven (37\%) percent of the respondents stated that because they were brought up in typical traditional areas, they grew up to see their mothers and other relatives using basically the local prints and for that matter that was what they know. This therefore indicates low perception of the local prints in the view of the respondents. The respondents having positive perception towards the foreign prints was influenced by the over 400 years of European dominance and the 113 years of colonisation and the use of basically foreign products has translated for likeness for foreign prints.

The impact of perception on the local prints.

Table 13. A table illustrating the impact of perception on the local textile prints.

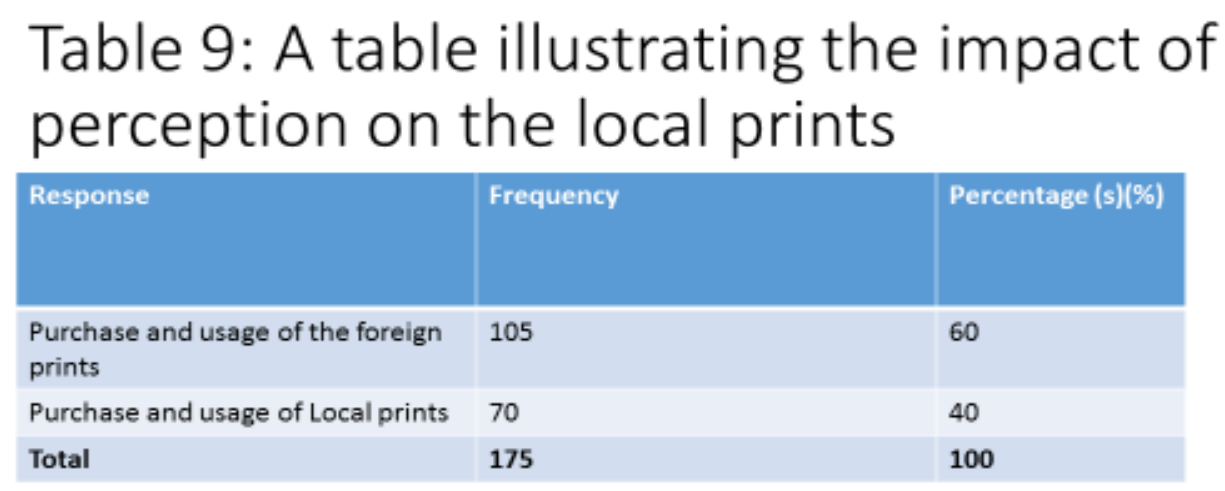

Source: Field survey JULY, 2018

From the table above, sixty (60\%) percent of the respondents prefer to buy and use foreign prints and further stated that most of their cloths apart from a few ones for special occasions and "Friday Wears" to work are made of local prints. On the other hand, forty (40) percent of the respondents stated that they have almost equal proportions of the local prints to the foreign prints in their wardrobe. Majority of these forty percent were female tertiary students who said they usually match up the local print (blouse) to their jeans trousers. It can be deduced from the above analysis that this perception impacts negatively on the sales of the local prints since the sales of the foreign prints as a result of perception is higher than the local prints.

\section{Conclusions and recommendations}

It was observed from the research that most of the respondents perceived Local Prints to be of high quality, but it is not as good as the foreign prints. Though the respondents were satisfied with the Local prints, they perceived the price to be high.

It was also established that the level of availability of the Local Prints is high in the market. Most respondents were of the view that the advertising efforts of the textile companies are not appealing and effective enough to persuade them into buying more of the textiles. The findings of the research work with respect to the objectives of the study led the researcher to conclude that the availability of the foreign prints among other factors have contributed to the perception of respondents towards Made-in-Ghana Local Prints.

In all, the respondents were fairly satisfied with Made-in-Ghana textiles and have fairly positive perceptions about Ghanaian prints in terms of quality, packaging, and branding but they raised serious concerns about the high prices and advertising ineffectiveness. Therefore, if Made-in-Ghana textiles are properly advertised it would not be affected by the issue of the country-of-origin effect. This proves that our perception about a given object influences the kind of attitude the consumer display towards the patronage and usage of the object.

From the study, It is recommended that the manufacturers of the Local Textiles Prints should improve on the packaging because packaging has the importance of differentiating homogenous products from available 
substitutes, it fortifies brand awareness, influence consumer brand choice, justifies product price and draws attention of customers, thereby changing any negative perception of the Local Prints.

The manufacturing companies in the local textile industry should intensify their promotional efforts such as advertising and public relation to reinforce the presence of their brands among the Ghanaian populace. This would affect customer's emotions and purchase decision making process thereby persuading them to purchase more of the Local Prints.

The Government of the country as a key regulator of the business environment has a role to play. The government of the country should develop more policies to enforce usage of the Local Prints. The government should enforce "National Every Day Wear" policy. The Senior High Schools and the Junior high schools and the Colleges of Education who wear school uniforms to class should be made to adopt a particular local print design to wear on every Friday in order to expand the policy of "National Friday Wear" but not to restrict it to the working population alone.

Government should increase the import duties and taxes put on the importation of foreign textiles to deter importers from entering the Ghanaian market with the foreign prints and the foreign prints but Ghanaian designs.

The government should give financial support such as tax free holidays and low interests on loans to Ghanaian textile companies to enable them produce more and enjoy economies of scale thereby reducing cost per unit price and thus make the local textile prints more competitive with the foreign brands.

Government should also invest more in cotton growing and other raw materials used by the local textiles companies so that the manufacturers can easily have access to raw materials which will intend reduce cost of production and thereby reducing the prices of their finished products. If prices are reduced, people will start patronizing because one of the negative perceptions towards the Made-in-Ghana textiles is about price. Being able to do this will positively influence the perception of the people towards our local products.

\section{References}

[1] Andrew, J. Durbin (1999) Fundamentals of Organizational Behaviour: An Applied Approach, Southwestern College Publishing, USA.

[2] Boone \& Kurt (2002), Contemporary Marketing. Southwestern Thompson Learning. USA.

[3] Chris Rice. (2000) Understanding Customers (2 ${ }^{\text {nd }}$ Edition), Butterworth Heinemann, Great .

[4] John, C. Mowen. Consumer Behaviour (2004) ( ${ }^{\text {rd }}$ Edition), Macmillan Publishing Company. New York. USA.

[5] Paul Peter, J. Jerry, C. Olson. Consumer Behaviour and Marketing Strategy ( $8^{\text {th }}$ Edition), McGraw Hill Companies Inc. New York, USA.

[6] Philip Kotler, Gary Armstrong. (2003) Principles of Marketing: Annotated Instruction Edition $6^{\text {th }}$ Edition), Prentice Hall, Englewood, New Jersey, USA.

[7] William, M. Pride, O. Ferrell, C. (2000), Pride-Ferrell Foundation of Marketing (2 ${ }^{\text {nd }}$ edition), Houghton Mifflin Company, Boston, USA.

[8] William, M. Pride, O. Ferrell, C. (2003), Pride-Ferrell Marketing Concepts and Strategies Expanding Edition). Houghton Mifflin Company, Boston, USA.

[9] Paul, D. Sweeny, Dean, B. McFarlin. (2000) Organization Behaviour: Solutions for Management. McGraw Hill Companies Inc. New York, USA.

[10] Solomon, R. Michael et al. (2005) Marketing: Real People, Real Choices (2 ${ }^{\text {nd }}$ edition). Pearson Prentice Hall. United Kingdom. 
[11] Schiffman and Walker J. (2006), The Country-Of-Origin Effects And Consumer Attitude To Buy Local Campaign: The Ghanaian Case, Journal Of Africa Business, 7(1/2), 183-199.

[12] Adersen, P.H. (2001), Relationship Development and Marketing Communication: Integrative Model, Journal Of Business and Industrial Marketing. Vol 16 No.3Pp. 7-22

[13] Baker, M.J. (1994), The marketing Book On Consumer Satisfaction: ( ${ }^{\text {rd }}$ edition) Butterworth Heinemann, Great Britain.

[14] Kotler, P. et al (1999) Principals of Marketing ( $2^{\text {nd }}$ edition) Prentice Hall Inc, London. "But Consumers Love Them" In: Wall Street Journal (Eastern Edition), P.18

[15] Opoku, R. A., And Akorli, P.A.K (2009), The Preference Gap: Ghanaian Consumers' Attitude Local and Imported Products. African Journal of Business Management, 3 (8), 350-357.

Social culturally, the EVERY - DAY- WEAR program will help in the true Ghanaian identity; intensify the promotion of the country's rich cultural heritage and image internationally. It will also help to reduce the barest minimum, the infiltration and blind adoption of foreign cultures especially among the youth; and help inculcate in them the pride of being Ghanaians. Appeals have been made to heads of government institutions and private establishment, religious groups and individuals to take up the challenge and promote the EveryDay Wear in their respective establishments not only for the survival and growth of the local textiles and government industry, but also create jobs for dressmakers, tailors, fashion designers etc. The initiative by government seeks to promote a unique Ghanaian identity through the extensive use of local textile fabric design. Ghanaians can be identified not only by our faces and languages but our dress as well. 